\title{
Antiproliferative activity of longan (Dimocarpus longan Lour.) leaf extracts
}

\author{
Ratna Puspita $^{1}$, Maria Bintang ${ }^{1 *}$, Bambang Pontjo Priosoeryanto ${ }^{2}$ \\ ${ }^{1}$ Department of Biochemistry, Faculty of Mathematics and Natural Sciences, IPB University, Bogor, Indonesia. \\ ${ }^{2}$ Department of Veterinary Clinic, Reproduction and Pathology, Faculty of Veterinary Medicine, IPB University, Bogor, Indonesia.
}

\begin{tabular}{l}
\hline ARTICLE INFO \\
\hline Received on: $11 / 01 / 2019$ \\
Accepted on: $24 / 02 / 2019$ \\
Available online: 08/05/2019
\end{tabular}

Key words:

Antiproliferative, cancer cell lines, cytotoxicity, in vitro, longan leaf.

\begin{abstract}
Longan (Dimocarpus longan Lour.) belongs to Sapindaceae family. We examined the antiproliferative activity of longan leaf extracts against cancer-derived cell cell lines in vitro. The tested samples were water extract, ethanol extract, $\mathrm{n}$-hexane fraction, ethyl acetate fraction, and water fraction of longan leaf. Cytotoxicity test is against brine shrimps that was screened using Brine Shrimp Lethality Test. Antiproliferative activity assay on WEHI-164 cells (mouse fibrosarcoma cancer cell), THP-1 cells (human peripheral blood acute monocyte cell), and vero cells (noncancer or normal cell) that was conducted using hemocytometer with Trypan Blue Dye exclusion. The 50\% lethality concentration $\left(\mathrm{LC}_{50}\right)$ value of water extract, ethanol extract, n-hexane fraction, ethyl acetate fraction, and water fraction were $854.64,305.81,446.55,1313.44$, and $1621.8 \mu \mathrm{g} / \mathrm{ml}$. Ethanol extract exhibited significant cytotoxic due to the lowest $\mathrm{LC}_{50}$ value. Ethanol extract was then used for further examination. The highest antiproliferative activity was achieved $44.93 \%$ by $600 \mu \mathrm{g} / \mathrm{ml}$ ethanol extract on WEHI-164 and $57.45 \%$ by $500 \mu \mathrm{g} / \mathrm{ml}$ ethanol extract on THP-1. It was significantly equal to doxorubicin antiproliferative activity. Ethanol extract dose had low effect to vero cells. This present study confirmed that the longan leaf ethanol extract possess marked antiproliferative activity on cancer-derived cell lines.
\end{abstract}

\section{INTRODUCTION}

Cancer is characterized by excessive, abnormal, and uncontrolled proliferation rolled growth of the body tissue cells. Cancer cells infiltrate the surrounding tissue (invasive) and continue to spread (metastasis). Cancer is classified as a degenerative disease that has the potential to cause death (Priosoeryanto et al., 2009). According to the World Health Organization (WHO) (2017), the global mortality rate related to cancer in 2015 was around 8.8 million. In some Asian countries including Indonesia, cancer is the number two cause of death after the heart disease with cancer deaths each year likely to increase (Ferlay et al., 2010).

\footnotetext{
"Corresponding Author

Maria Bintang, Department of Biochemistry, Faculty of Mathematics and Natural Sciences, Bogor Agricultural University, Bogor, Indonesia. E-mail:maria_bintang@yahoo.com
}

The most applied cancer treatment is chemotherapy by using doxorubicin. However, doxorubicin can cause cardiotoxicity and many other side effects (Dashora et al., 2011). The side effects due to the activity of doxorubicin are not only to cancer cells but also affects normal cells (NCI, 2007). The development of cancer treatment is still developed to find out the effective one.

The secondary metabolites usually used as a defense mechanism of the plants. Some people use this secondary metabolites for the treatment of human diseases. Secondary metabolites derived from plants are one of the treatments for cancer disorder. Secondary metabolites compounds have a bioactivity that can control the proliferation of cancer cells (Ayoola et al., 2008). This process is a promising for treating cancer without decreasing the quality of life.

Indonesia is a megabiodiversity country with a lot of promising medicinal plants. One of them is a longan plant (Dimocarpus longan Lour.). Longan is an Indonesian fruit plant that belongs to Sapindaceae family. Longan leaf possesses various pharmacological activities such as antihepatitis, antioxidant, and anti-tumor (Ayoola et al., 2008; Apriyanto et al., 2016; Salamah 
and Widyasari, 2015). However, the antiproliferative activity of specific secondary metabolites of longan leaf has not yet be determined; therefore, this present study was conducted to examine the antiproliferative activity of longan leaf extract on some cancer-derived cell lines.

\section{MATERIAL AND METHODS}

\section{Plants materials}

The fresh longan leaf (Dimocarpus longan Lour.) was collected from Cikabayan-Bogor, Indonesia, in February 2018. The identity of sample was authenticated from Herbarium Bogoriense, Research Centre for Biology in Indonesian Institute of Science, Bogor, Indonesia.

\section{Extraction}

The extraction of longan leaf was conducted according to the modified method of Apriyanto et al. (2016) and Sari and Triyasmono (2017). Longan leaves were room dried for 7 days. The dried leaves were than coarsely powdered using a mechanical grinder. The water extract was done by the reflux method, while ethanol extract was done by ultrasonication. Ethanol extract was fractionated using liquid-liquid extraction and resulted in n-hexane fraction, ethyl acetate fraction, and water fraction. All extracts and fractions were vacuum evaporated at $40^{\circ} \mathrm{C}$.

\section{Cytotoxicity assay}

Cytotoxicity assay of extracts and fractions was conducted according to the modified method of Rampel and Tombuku (2015). It was conducted using Brine Shrimp Lethality Test (BSLT) method. Brine shrimp (Artemia salina) larvae were placed and hatched for 48 hours with constant oxygen supply and under the light at room temperature $\left(25^{\circ} \mathrm{C}\right)$. The stock extracts solution $(2,000 \mu \mathrm{g} / \mathrm{ml})$ made of $10 \mathrm{mg}$ extract, $50 \mu \mathrm{l}$ Tween 80 , and $10 \mathrm{ml}$ of seawater into a test tube. It was diluted into 1,000, 500,100 , and $10 \mu \mathrm{g} / \mathrm{ml}$. All extracts and fractions were carried out at triplicates. The dead larvae were counted after the incubation under TL light $14 \mathrm{~W}$ for 24 hours. The similar procedure (without added extracts or fractions) was applied as the negative control. The data of surviving brine shrimp were analyzed with Minitab 16.0 program for probit analysis to determine 50\% lethality concentration $\left(\mathrm{LC}_{50}\right)$ values at $95 \%$ confidence intervals.

\section{Antiproliferative activity assay}

Antiproliferative activity assay of potential extract or fraction was conducted according to the modified method of Priosoeryanto et al. (1995). In vitro antiproliferative activity applied on WEHI-164 cells, THP-1 cells, and vero cells. Each type cells of $25 \mu \mathrm{l}$ were cultured in the tissue culture 24-well plates at a density of $7 \times 10^{5}$ cells $/ \mathrm{ml}$. It was, respectively, maintained on the media made of $850 \mu$ l Dulbecco's Modified Eagle's Medium, supplemented with $10 \mu \mathrm{l}$ fetal calf serum $10 \%, 5 \mu \mathrm{l}$ antibiotics $1 \%$ (penicillin and streptomycin), and $10 \mu \mathrm{l}$ fungizone. The extract was dissolved in the tube containing $100 \mu$ of dimethyl sulfoxide in sterile distilled water. The tested concentrations of extract were 100, 200, 300, 400, 500, and $600 \mu \mathrm{g} / \mathrm{ml}$ in triplicates. The treartment control made of cultured cells on the media with $25-\mu l$ extract, the negative control made of cultured cells on the media without extract, and the postive control made of cultured cells on the media with doxorubicin $(100 \mu \mathrm{g} / \mathrm{ml})$. All plates were incubated in a humidified atmosphere of $5 \% \mathrm{CO}_{2}$ at $37^{\circ} \mathrm{C}$. The cells were harvested when the cells growth in the negative control was confluent ( \pm 3 days). The cells were then stained using Trypan Blue Dye Exclusion. The average of the total number of the cells on each well was counted under light microscope at $100 \times$ magnification using Improved Neubauer Hemocytometer.

\section{Statistical analysis}

Data of cell proliferation were analyzed using one-way analysis of variance by Minitab 16.0 for Windows (Minitab.Inc.). Mean separation test between treatments was performed using Tukey test. $p$ value $<0.05$ was considered statistically significant.

\section{RESULTS AND DISCUSSION}

The water extract, ethanol extract, ethyl acetate fraction, $\mathrm{n}$-hexane fraction, and water fraction yield were $20.11 \%, 8.22 \%$, $7.10 \%, 23.44 \%$, and $69.46 \%$, respectively. Extraction by using water solvent resulted in higher yield than $70 \%$ ethanol. The fractionation of ethanol extract, the water fraction produced the higher yield compared with the ethyl acetate and n-hexane fractions. The difference in polarity of the extracted compound is due to the polarity of the solvent. Extraction results showed the higher solvent polarity and the higher extract yield. These results showed that mainly phytochemical content of longan leaf is polar compounds. The water grade of longan leaf simplicia has been controlled to preserve the quality of the extract. In addition, sample preservation, time and method of picking the leaf, sample preparation, and selection of solvents in extraction must be controlled to preserve the quality of the extract.

Cytotoxic activity of longan leaf extract on shrimp larvae can be seen in Table 1. Death of shrimp larvae was confirmed by the effect of extracting and confirmed by the absence of mortality of shrimp larvae in the negative control group. The extract cytotoxicity was determined based on the $50 \%$ mortality response of shrimp larvae $\left(\mathrm{LC}_{50}\right)$. Plant extracts are considered toxic if they have $\mathrm{LC}_{50}$ value less than $1,000 \mu / \mathrm{ml}$ (Sukmarianti et al., 2013). Ethyl acetate fraction and water fraction of longan leaf have $\mathrm{LC}_{50}$ values greater than $1,000 \mu \mathrm{g} / \mathrm{ml}$. It means that ethyl acetate fraction and water fraction have no cytotoxic activity.

Table 1. Cytotoxic activity of longan leaf extracts and fractions against brine shrimps.

\begin{tabular}{lccccc}
\hline Sample & \multicolumn{6}{c}{$\%$ brine shrimp mortality $($ concentration in $\boldsymbol{\mu g} / \mathbf{m l})$} & $\mathbf{L C}_{50}(\boldsymbol{\mu g} / \mathbf{m l})$ \\
& $\mathbf{1 0}$ & $\mathbf{1 0 0}$ & $\mathbf{5 0 0}$ & $\mathbf{1 0 0 0}$ & \\
\hline $\begin{array}{l}\text { Water } \\
\text { extract }\end{array}$ & $0.00 \pm 0.00$ & $0.00 \pm 0.00$ & $33.33 \pm 0.67$ & $56.67 \pm 0.33$ & 854.64 \\
$\begin{array}{l}\text { Ethanol } \\
\text { extract }\end{array}$ & $23.33 \pm 0.33$ & $36.67 \pm 0.33$ & $76.67 \pm 0.67$ & $96.67 \pm 0.33$ & 305.81 \\
$\begin{array}{l}\text { n-hexane } \\
\text { fraction }\end{array}$ & $20 \pm 0.58$ & $36.67 \pm 0.33$ & $56.67 \pm 0.33$ & $86.67 \pm 0.67$ & 446.55 \\
$\begin{array}{l}\text { Ethyl } \\
\text { acetate } \\
\text { fraction }\end{array}$ & $0.00 \pm 0.00$ & $20.00 \pm 0.00$ & $26.67 \pm 0.33$ & $30.00 \pm 0.00$ & $>1,000$ \\
$\begin{array}{l}\text { Water } \\
\text { fraction }\end{array}$ & $6.67 \pm 0.33$ & $10.00 \pm 0.00$ & $10.00 \pm 0.00$ & $26.67 \pm 0.67$ & $>1,000$ \\
\hline
\end{tabular}

Percentages of brine shrimp mortality were expressed as mean \pm SEM. 
Nevertheless, the water extracts, ethanol extracts, and n-hexane fractions of longan leaf have $\mathrm{LC}_{50}$ values smaller than $1,000 \mu \mathrm{g} /$ $\mathrm{ml}$. It means that water extract, ethanol extract, and n-hexane fraction showed cytotoxic activity.

This study compared the mortality of shrimp larvae and further investigated the inhibitory activity on cancer cells. Several studies have shown that BSLT has a positive correlation with various cancer cell tests (Sukmarianti et al., 2013). BSLT was applied to evaluate toxicity of longan leaf extracts that potentially showed antiproliferative activity against cancer cells. The extract with the lowest $\mathrm{LC}_{50}$ value has the potential as an anticancer drug ingredient.

The results of this study showed that the ethanol extract of longan leaf has the lowest $\mathrm{LC}_{50}$ value compared with water extract and n-hexane fraction. Cytotoxicity of crude extracts also depends on the choice of the extraction solvent (Tannoury et al., 2017). Cytotoxic activity can be produced from secondary metabolites contained in the extract (Handayani et al., 2018). These previous study supported that the cytotoxic activity of longan leaf depends on their phytochemical content; therefore, the ethanol extract has more potential as an antiproliferative agent. Ethanol extract was preferred as antiproliferative activity assay in vitro.

Antiproliferative activity assay of ethanol extract was performed on WEHI-164 cell, THP-1 cell, and vero cell. The effect of ethanol extract on these cells is shown in Figure 1. The results showed that the ethanol extract of longan leaf significantly was able to inhibit the proliferation of these two cancer-derived cell lines compared with negative control. The number of WEHI-164 and THP-1 cells, respectively, decreased when the concentration of extract increased. Ethanol extract of longan leaf slowly inhibit the proliferation of vero cells.

The ethanol extract of longan leaf showed different antiproliferative activities in both cancer-derived cell lines. Priosoeryanto et al. (2002) reported that the anticancer activity of an extract depends on the cancer cell lines used. Abd ElMonaem et al. (2018) reported that the selectivity of some compound against cancer-derived cell lines were different than vero cells. Treatment of $200 \mu \mathrm{g} / \mathrm{ml}$ ethanol extract on THP-1 cells, $100 \mu \mathrm{g} / \mathrm{ml}$ ethanol extract on WEHI-164 cells, and $400 \mu \mathrm{g} / \mathrm{ml}$ ethanol extract on vero cells showed significant antiproliferative activity than negative control group. Treatment of $400 \mu \mathrm{g} / \mathrm{ml}$ ethanol extract on THP-1

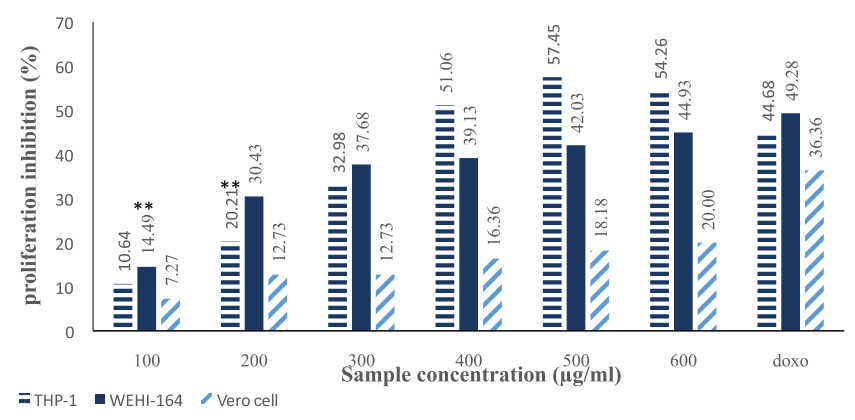

Figure 1. Percentage of proliferation inhibition WEHI-164, THP-1, and vero cells after the treatment with ethanol extract of longan leaf. The data are expressed as percentage of antiproliferative activity, as compared with the negative control $(100 \%)$. The start level of significance is denoted as follows: $* * p<0.05$. cells and $300 \mu \mathrm{g} / \mathrm{ml}$ ethanol extract on WEHI-164 cells showed significant antiproliferative activity than $100 \mu \mathrm{g} / \mathrm{ml}$ doxorubicin. Treatment of $500 \mu \mathrm{g} / \mathrm{ml}$ ethanol extract on THP-1 cells, $600 \mu \mathrm{g} /$ $\mathrm{ml}$ ethanol extract on WEHI-164 cells, and $600 \mu \mathrm{g} / \mathrm{ml}$ ethanol extract on vero cells showed the highest antiproliferative activity. Nevertheless, treatment of $600 \mu \mathrm{g} / \mathrm{ml}$ ethanol extract (highest concentration) on vero cells showed antiproliferative activity less than $100 \mu \mathrm{g} / \mathrm{ml}$ doxorubicin. These results revealed that the ethanol extract of longan leaf had antiproliferative activity more effective than doxorubicin.

The difference in antiproliferative activity of extract can be caused by differences in membrane receptors and cell nuclei in cancer cell lines (Priosoeryanto et al., 2002). WEHI-164 cell is very sensitive to human cytotoxic monocytes, to human Tumor Necrosis Factor and to lymphotoxins. The increased sensitivity of tumor cells to TNF- $\alpha$ causes lysis. THP-1 cells have Fc and $\mathrm{C} 3 \mathrm{~b}$ receptors and have cytoplasmic immunoglobulins. THP-1 cells can be differentiated into immature dendritic cells (ATCC, 2014). Ethanol extract of longan leaf can increase sensitivity or susceptibility to both of cancer-derived cell lines compared with vero cells.

Ayoola et al. (2008) reported that the ethanol longan leaf extract contained flavonoids and triterpenoids. Flavonoids and triterpenoids are toxic to shrimp larvae in certain concentrations. Terpenoids have antioxidant capacity functions. Nevertheless, terpenoid has no antiproliferation functions to cancer cells. This effect is caused by the content of phenolic compounds which act as a primary antioxidant through donor of $\mathrm{H}$ atoms from the hydroxyl group quickly to radicals. Antioxidant radicals formed from the mechanism are stable because of the delocalization of unpaired electrons on the aromatic ring (Han and Bakovic, 2015).

Tettey et al. (2014) reported that there is strong correlation between phenolic content and antiproliferative activity. González et al. (2017) reported that a potentially cytotoxic source because of its high antioxidant capacity and total phenolic content. Paul and Ramasubbu (2017) stated that the cytotoxicity of the crude extracts may be due to their higher antioxidant potentials or due to the synergistic effect of the multiple bioactive components present in the extract. The cytotoxic activity can affect and disrupt the fundamental mechanisms associated with cell growth, mitotic activity, differentiation, and function (Handayani et al., 2018). These compounds were reported that they have antioxidant activity, with capacity to scavenge reactive oxygen species (ROS) (Han and Bakovic, 2015; Hertzog and Tica, 2012).

ROS are toxic and cause various diseases including cancer. Anticancer mechanism of flavonoid based on their antioxidant properties is associated with their ability to scavenge free radicals, inhibit the enzymes involved in ROS formation, and block the oxidation of cellular and extracellular compounds (Han and Bakovic, 2015). Moreover, flavonoids contribute to modulating pathway of cancer proliferation, arresting the cell cycle, inducing apoptosis, and inhibiting angiogenesis (Hertzog and Tica, 2012; Katyal et al., 2014). Paul and Ramasubbu (2017) stated that the resistance of programmed cell death or apoptosis is an integrated part of the cancer cell development and re-inducing the apoptosis mechanism would be a good indicator of anticancer agent. Morphological studies by microscope on cancer cells indicated certain events of apoptosis such as nuclear shrinkage, 
membrane blebbing, and vacuolization of cells. This was further supported by activation of caspases 3 and 7 (Dahham et al., 2017).

Zakaria (2000) reported that flavonoids have potential to be anticancer with a mechanism that inhibits the action of the tyrosine kinase enzyme. Tyrosine kinase enzymes are enzymes that play a role in cell transduction signals, namely, by regulating the cell's advanced cycle, regulation of transcription, cell transformation, proliferation, differentiation, and apoptosis. Mohamed et al. (2017) confirmed that the strong cytotoxic activity of some active compounds over cancer-derived cell lines may act on the same enzyme target where epidermal growth factor receptor (EGFR) inhibitor. This present study revealed that the ethanol longan leaf extract can induce apoptosis on cancer-derived cells.

\section{CONCLUSION}

The ethanol extract of longan leaf exhibited cytotoxic activity. It possessed significant antiproliferative activity on WEHI-164 and THP-1 cancer-derived cell lines. It possessed low antiproliferative activity on vero cells. Hence, it was suggested as a potent natural anticancer.

\section{ACKNOWLEDGMENTS}

The authors are thankful to Faculty of Sciences for all laboratory facilities and Faculty of Veterinary Medicine, IPB University, Indonesia, for providing cancer-derived cell lines.

\section{CONFLICT OF INTEREST}

The authors declare that they have no competing interests regarding the publication of this paper.

\section{FINANCIAL SUPPORT}

\section{None.}

\section{REFERENCES}

Abd ElMonaem HS, Abdel-Aziz NI, Morsy MA, Badria FA, ElSenduny F, El-Ashmawy MB, Moustafa MA. Synthesis, in vitro antiproliferative evaluation and molecular docking of new tetrazolechalcone and tetrazole-pyrazoline hybrids. J Appl Pharm Sci, 2018; 8:075-87.

Apriyanto DR, Aoki C, Hartati S, Hanafi S, Kardono LBS, Arsianti A, Louisa M, Sudiro TM, Dewi BE, Sudarmono P. Antihepatitis $\mathrm{C}$ virus activity of a crude extract from longan (Dimocarpus longan Lour.) leaves. Jpn J Infect Dis, 2016; 69:213-20.

American Type Culture Collection (ATCC). WEHI 164 (ATCC $\AA$ CRL1751 ${ }^{\mathrm{TM}}$ ). [Online] 2014. Available via http://www.atcc.org (Accessed 8 November 2018).

Ayoola GA, Coker HAB, Adesegun SA, Obaweya K, Ezennia EC, Atangbayila TO. Phytochemical screening and antioxidant activities of some selected medical plants used for malaria therapy in Southwstern Nigeria. J Pharm Res, 2008; 7:1019-24.

Dahham SS, Asif M, Sandai D, Majid AMA, Harn GL. Antiproliferative and apoptotic activity of crude skin secretion from Malaysian Toad (Bufo asper) on in vitro colorectal cancer cells. J Appl Pharm Sci, 2017; 7:001-6.

Dashora N, Sodde V, Bhagat J, Prabhu KS, dan Lobo R. Antitumor activity of Dendrophthoe falcata against Ehrlich Ascites carcinoma In Swiss albino mice. Pharmaceut Crops, 2011; 2:1-7.
Ferlay J, Shin HR, Bray F, Forman D, Mathers C, Parkin DM. Estimates of worldwide burden of cancer in 2008: GLOBOCAN 2008. Int J Cancer, 2010; 127:2893-917.

Rampel MJ, Tombuku JL. Pengujian fitokimia dan toksisitas ekstrak etanol jantung pisang kapok (Musa paradisiaca Linn.) dengan metode Brine Shrimp Lethality Test (BSLT). J Sainsmat, 2015; 4:136-47.

González M, Samudio I, Sequeda-Castañeda LG, Celis C. Cytotoxic and antioxidant capacity of extracts from Vaccinium meridionale Swartz (Ericaceae) in transformed leukemic cell lines. J Appl Pharm Sci, 2017; 7:024-30.

Handayani D, Rasyid W, Rustini, Zainudin EN, Hertiani T. Cytotoxic activity screening of fungal extracts derived from the west sumatran marine sponge Haliclona fascigera to several human cell lines: Hela, WiDr, T47D and Vero. J Appl Pharm Sci, 2018; 8:055-8.

Han N, Bakovic M. Biologically active triterpenoids and their cardioprotective and anti-inflammatory effects. J Bioanal Biomed, 2015; S12:1-11.

Hertzog DI, Tica OS. Molecular mechanisms underlaying the anti-cancerous action of flavonoids. Curr Health Sci J, 2012; 38:145-9.

Katyal P, Bhardwaj N, Khajuria R. Flavonoids and their therapeutic potential as anticancer agents; biosynthesis, metabolism and regulation. World J Pharm Pharm Sci, 2014; 3:2188-216.

Mohamed AAB, Badria FA, Maarouf AR, Abdel-Aziz NI, ElSenduny F, Abdel-Aziz AM, Bayomi SM. Synthesis, antitumor evaluation and molecular modeling study of novel benzimidazoles and pyrazinobenzimidazoles. J Appl Pharm Sci, 2017; 7:206-14.

National Cancer Institute (NCI). Chemotherapy and you: support for people with cancer. [Online] 2007. Available via www.cancer. gov/cancertopics/chemotherapy_andyou (Accessed 20 January 2018).

Paul T, Ramasubbu S. The antioxidant, anticancer and anticoagulant activities of Acanthus ilicifolius L. roots and Lumnitzera racemosa Willd. leaves, from southeast coast of India. J Appl Pharm Sci, 2017; 7:081-7.

Priosoeryanto BP, Tateyama S, Yamaguchi R, Uchida K Antiproliferation and colony-forming inhibition activities of recombinant feline interferon (rFeIFN) on various cells in vitro. Can J Vet Res, 1995; 59:67-9.

Priosoeryanto BP, Huminto H, Wibawan IWT, Tiuria R, Tateyama S. Morphological characteristics of in vivo cultured cells derived from tumor in domestic animals. Hayati, 2002; 9:49-54.

Priosoeryanto BP, Sari R, Tiuria R, Darusman LK, Purwakusumah $\mathrm{ED}$, Nurcholis W. In vitro antiproliferation activity of temulawak (Curcuma xanthorriza Roxb.) ethanol extract on MCA-B1 and MCM-B2 derived tumor cell lines. Hemera zoa Indones J Vet Sci Med, 2009; 1:29-35.

Salamah N, Widyasari E. Antioxidant activity of methanolic extract of Longan (Euphoria longan (L) Steud.) leaves using 2,2'diphenyl1-picrylhydrazyl radical scavenging method. Pharmaçiana, 2015; 5:25-34.

Sari DI, Triyasmono L. Rendemen dan flavonoid total ekstrak etanol kulit batang bangkal (Nauclea subdita) dengan metode maserasi ultrasonikasi. J Pharmsci, 2017; 04(01):48-53.

Sukmarianti NW, Suaniti NM, Swantara IMD. Identifikasi dan uji aktivitas antikanker ekstrak spons Ianthella basta terhadap larva Artemia salina L. Cakra Kimia (Indones J App Chem), 2013; 1(1): $14-9$.

Tannoury M, Saab A, Harb JEN, Makhlouf H, Assaf MD. In vitro cytotoxic activity of Laurencia papillosa, marine red algae from the Lebanese coast. J Appl Pharm Sci, 2017; 7:175-9.

Tettey CO, Ocloo A, Nagajyothi PCN, Lee KD. An in vitro analysis of antiproliferative and antimicrobial activities of solvent fractions of Taraxacum officinale (Dandelion) leaf. J Appl Pharm Sci, 2014; 4:041-5 
World Health Organization (WHO). Prevalence of cancer worldwide. [Online] 2017. Available via http://www.who.int/mediacentre/ factsheets/fs297/en/ (Accessed 27 September 2017).

Zakaria FR, Susanto H, Hartoyo A. Pengaruh konsumsi jahe (Zingiber officinale roscoe) terhadap kadar malonaldehida dan vitamin E plasma pada mahasiswa di Pesantren Ulil Albab Kedung Badak. Bull Teknol Indust Pangan, 2000; XI:36-40.
How to cite this article:

Puspita R, Bintang M, Priosoeryanto BP. Possible antiproliferative activity of longan (Dimocarpus longan Lour.) leaf extracts. J Appl Pharm Sci, 2019; 9(05):102-106. 